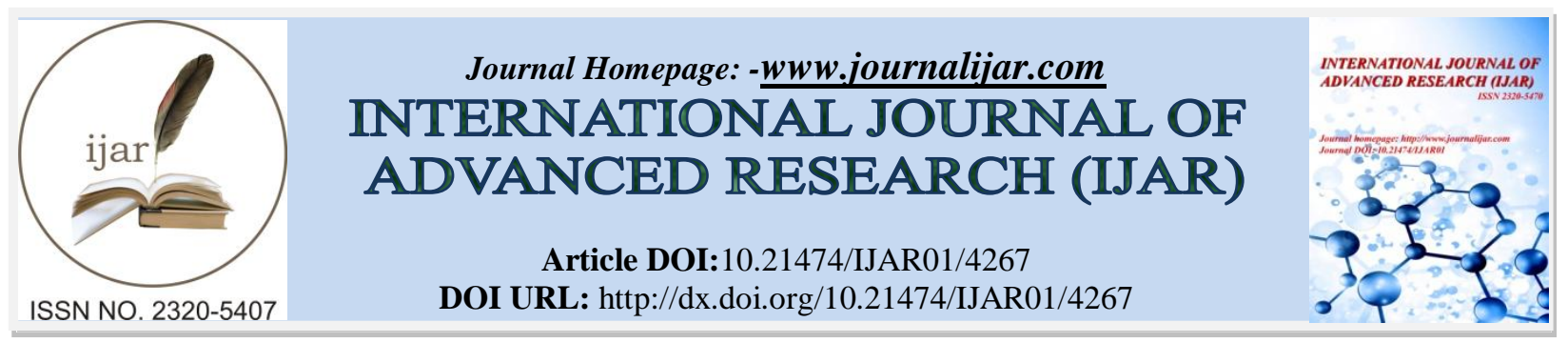

RESEARCH ARTICLE

\title{
SOCIO-ECONOMIC IMPACT OF MGNREGA ON RURAL WORKERS: ANEMPIRICAL STUDY.
}

\author{
Alka Jain. \\ Research Scholar, Department of Economics, Sri Satya Sai University of Technology and Medical sciences \\ Sehore,M.P.
}

\section{Manuscript Info}

Manuscript History

Received: 27 March 2017

Final Accepted: 30 April 2017

Published: May 2017

Key words:-

MGNREGA, Socio-economic, Rural workers,

Development, Migration.

\section{Abstract}

Agribusiness assumes a vital part in business era in creating nations. It keeps on being the backbone of the Indian economy regarding its share of business. In India the Mahatma Gandhi National Rural Employment Guarantee Act, 2005 (MGNREGA) has come up which ensures 100 days of work in a monetary year to any rustic family unit whose grown-up individuals will do untalented manual work. MGNREGA gives work to their employment and the general population who were ignorant was likewise given an open door. This keeps the relocation of the general population by giving other wage producing exercises. In this study we have also tried to analysis the socio-economic condition of rural workers.

Copy Right, IJAR, 2017,. All rights reserved.

\section{Introduction:-}

Mahatma Gandhi National Rural Employment Guarantee Act (MGNREGA) is considered as a "Silver Bullet" for annihilating country destitution and unemployment, by method for creating interest for profitable work compel in towns. Country neediness and unemployment in India have developed in an exceptional way amid the most recent couple of decades. There is a developing frequency of absence of education, visually impaired confidence, hungry individuals, mal-sustained youngsters, frail pregnant ladies, agriculturist suicides, starvation passing, relocation coming about because of deficient business, neediness, and the disappointment of subsistence creation amid dry spells. India (GOI) sanctioned the National Rural Employment Guarantee Act (NREGA) in 2005. It is the greatest neediness easing program on the planet which is begun with an underlying cost of Rs. 11,300 crore in year 2006-07 and now it is Rs. 40,000 crore (2010-11). This Act is currently called as Mahatma Gandhi NREGA. The Act gives a lawful certification to 100 days of work in each money related year to grown-up individuals from any provincial family unit will to do open business related incompetent manual work at the statutory the lowest pay permitted by law. In this manner it is an all-inclusive program.

Agriculture assumes a significant part in work era in creating nations. It keeps on being the pillar of the Indian economy as far as its share of business. However, the commitment of agribusiness to Indian Gross Domestic Product is low (it now remains at around 15 percent as indicated by Economic overview 2010-11) and is declining yet, 75 percent of country workforce (Census 2001) is occupied with horticulture (rustic populace contains 72 percent of aggregate populace in India) and it possesses a vital place in the monetary and social texture of India. It remains the biggest area engrossing the Indian workforce. Horticultural workers constitute 45 percent of the farming workforce (Census 2001). Landless family units which shape the most minimal wage quintile in India are totally subject to rural wage work for their wage. They generally work in agribusiness as easygoing workers since customary wage contracts in horticulture are not very many (National Sample Survey 2004). As far as sexual orientation piece, 
around 74 percent of female work constrain in India is occupied with agribusiness and there is developing feminization of agrarian workforce as men can discover exchange non-cultivate openings, however females in rustic zones have not possessed the capacity to access non-cultivate occupations.

\section{Impacts Of Mgnregs:- \\ Wage Hike:-}

It was found that MGNREGS majorly affected the farming at the season of its presentation in 2006. In prior the wages of the laborers were low; Rs.100/day for a male specialist and Rs.70/day for a female specialist, as uncovered by the respondents. So when the plan was presented, there was a monstrous stream of horticultural works towards the MGNREGS in light of a higher wage rate of Rs.125 given by it. In any case, later when the market wages of the specialists expanded, the male laborers moved back to their before occupations. It was supported by the low number of guys in the specimen populace (5\%) directly. Subsequently, MGNREGS is dependable in a route for the wage climb in the farming work advertises. The wage rate settled by the MGNREGS is considered as a standard the lowest pay permitted by law underneath which the market compensation can't go in light of the fact that any such diminishment would again prompt exchange of work from the farming part to the MGNREGS. The climb in wage rates from 2006 to 2011 in the market and under MGNREGS for both male and female specialists is portrayed.

\section{Monetary Empowerment:-}

The usage of MGNREGS has given financial empowerment to provincial ladies since it offers same wage rates to male and female specialists. Henceforth, there is a high rate of female work cooperation in the MGNREGS on the grounds that they get a wage proportionate to the market wage and think that its more agreeable in light of the fact that it includes less drudge. Another fascination for the female specialists is that MGNREGS gives 100 days of ensured work, which the female laborers don't know of getting on working somewhere else. A portion of the female respondents opined that working in an administration plan was more conscious than functioning as Agri-workers.

\section{Gift to Illiterate and Aged Males:-}

It was fascinating to discover why in spite of higher wage rates in the market, there was as yet male interest in MGNREGS. It was more pertinent in light of the fact that the dominant part of farming workers in estates and are not favored in the work showcase on intersection the age of 50 years. Additionally, there is rate of absence of education. The cooperation of male laborers in MGNREGS, however little (5\%) was dissected on the premise of the age gathering and instructive level. It was found that 50 for each penny of the specimen male populace were in the age section of 40-60 years and the youthful specialists (25-40 years) were just 10 for each penny. The training insightful dispersion of the specimen male populace demonstrated that 20 for every penny were uneducated people and 80 for each penny had instruction just up to center level. In this way, MGNREGS has been a gift for these matured and uneducated/low-taught male specialists whose request in the work market was unimportant. Likewise, these specialists were not willing to attempt hard work but rather could be invested in MGNREGS because of delicate work.

\section{Review of literature:-}

The start of measures that would make the 'right to work' a legitimate qualification brought about a concentrated level headed discussion on the way of the privilege. One contention was that the procedure of development with redistribution is presently imagined through work, instead of the prior endeavors that depended on stream down hypotheses. By guaranteeing standard work at least wages, the push was to be on "business to begin with, with development as a result", as opposed to the other way around (Bhaduri 2005).

This way towards full business alone would, it is able to be contended, guarantee the "financial substance of participatory majority rules system" and consider "improvement with nobility" (Ibid). The fact of the matter being underlined is that the 'right to work' ought not to be diminished to a push to pad the negative impacts of globalization through the production of wage business and resources in rustic regions. The expectation was that "NREG would can possibly lead the economy towards a work concentrated development way, particularly in the light of the low and declining development rate of profitable business". (NCEUS, 2006) Thus the wage-work program should be seen from a long haul viewpoint, with a solid arranging segment. It ought to be dovetailed with progressing advancement endeavors, joining decentralized arranging and usage, expertise preparing and upkeep of open resources. In the long run it ought to assimilate workers into standard business. Moreover, the acknowledgment of OK employment through a 'rights based approach' like MGNREGA is viewed as dependent upon a specific least government disability without which many meriting individuals might be off guard. 
MGNREGA as designed is only a rudimentary right. If we raise the question whether the right to work as enshrined in NREGEA is a "right to a job" or "right to employment", the answer is quite clear. NREGA does not guarantee a regular job. It only guarantees certain minimum days of work at an assured minimum wage so as to enable the underemployed or unemployed workers earn a minimum supplementary income to overcome deprivation or distress migration.

While provision of work enhances both demand and the home market, the works executed are expected to increase development potential through their productivity. The caveat is that the quality of employment and productivity of work are critical in enhancing the content of any attempt towards the right to work (Rodgers 2009).

\section{Objectives of the study:-}

- To analyze the socio-economic impact of MGNREGA on rural labors/workers.

- To Evaluation of the impact of MGNREGA development factors in perspective of Beneficiaries.

\section{Research Methodology:-}

In order to carry out any research investigation, there is a need of a systematic method and to adopt a well-defined procedure for each and every research. There is also a need methodology of any research constitutes the selection of representative sample of the universe or the general population, application of the appropriate research tools and the techniques.

To fulfill the objectives of our study following methodology will use for the study and report preparation.

\section{Research Design:-}

Research Design refers to pattern or an outline of a research proposal. It comprises a series of prior decision that is taken together and provides a plan for executive a research report.

As different Rural Gram Panchayat will covered in the study, so it will be altogether a self-reported survey and research design to conduct the study will be a survey design.

\section{Sources of Data:-}

Both primary and secondary methods will be used for collection of data. Semi structured questionnaire was used as primary source of collecting data for the completion of study. The questionnaire comprises different parts. Annual reports, Library research (articles, journals, dissertations books, accessed database, etc.) will be used as secondary source for collecting data.

\section{Sample Technique:-}

*Non Probability sampling

Convenient Sampling will be the type of sampling which will be used to collect the data from the respondents rural gram panchayat in Sehore were covered as the area for the research work.

\section{Sample unit:-}

Rural Gram Panchayat in Sehore District

\section{Sample size:-}

100 Respondents

\section{Sampling Area:-}

Sehore (Rural Areas)

\section{Research Instruments:-}

Research instrument serve as measurement tools. Research instrument was including as questionnaire, personal interview, observation, self-report instrument or scale etc. 
Data Analysis \& Interpretation:-

Table 1:-

\begin{tabular}{|c|c|c|}
\hline Sr. No. & Gender & Respondents \\
\hline 1 & Male & 65 \\
\hline 2 & Female & 35 \\
\hline & Total & 100 \\
\hline
\end{tabular}

Table 2:-

\begin{tabular}{|c|c|c|}
\hline Sr. No. & Age & Respondents \\
\hline 1 & Below 25 & 25 \\
\hline 2 & $25-40$ & 15 \\
\hline 3 & $40-60$ & 35 \\
\hline 4 & 60 above & 25 \\
\hline
\end{tabular}

Table 3:-

\begin{tabular}{|c|c|c|c|}
\hline Sr. No. & Tehsil & District & Respondents \\
\hline 1 & Sehore & Sehore & 25 \\
\hline 2 & Ashta & Sehore & 25 \\
\hline 3 & Nasrullganj & Sehore & 25 \\
\hline 4 & Ichhawar & Sehore & \\
\hline
\end{tabular}

Table 4:-

\begin{tabular}{|c|c|c|}
\hline Sr. No. & Respondents & Caste \\
\hline 1 & 28 & General \\
\hline 2 & 21 & OBC \\
\hline 3 & 26 & SC \\
\hline 4 & 16 & ST \\
\hline 5 & 09 & Others \\
\hline
\end{tabular}

Table 5:-

\begin{tabular}{|c|c|c|}
\hline Sr. No. & Income Per Month & Respondents \\
\hline 1 & Below 2000 & 45 \\
\hline 2 & $2000-5000$ & 25 \\
\hline 3 & $5000-8000$ & 20 \\
\hline 4 & 8000 above & 10 \\
\hline
\end{tabular}

Table 6:-Caste wise distribution of the facilities.

\begin{tabular}{|c|c|c|c|c|c|}
\hline Facilities & General & OBC & SC & ST & Others \\
\hline Connection & $\mathbf{2 8}$ & $\mathbf{2 1}$ & $\mathbf{2 6}$ & $\mathbf{1 6}$ & $\mathbf{0 9}$ \\
\hline Electricity & 17 & 15 & 19 & 09 & 04 \\
\hline Water & 17 & 15 & 19 & 09 & 04 \\
\hline Without Connection & 11 & 06 & 07 & 07 & 05 \\
\hline
\end{tabular}

\section{Discussion \&Findings of study:-}

- The number of days, the laborers worked under MGNREGA projects was relapsed on the elements like age, sex, training, family size and landholding size of the specialists to break down the connection between the quantity of days worked under the program and the contributing components.

- The rate increment in the pay earned subsequent to working under MGNREGA program was 8.04 and this expansion was factually critical. In absolute pay, the share of rural pay was most elevated (69\%), trailed by salary from non-horticulture (21\%) and wage from MGNREGA $(10 \%)$.

- It was because of the way that inclination to work under the program was simply after farming, since agribusiness guaranteed their nourishment security.

- It is watched that the effect of MGNREGS is vital among the sleeved laborers to build the wage salary in the Study area. 


\section{Conclusion:-}

The review has demonstrated that MGNREGA program frequently represents the issue of work shortage for a portion of the farming operations connected to market wage rates. As an outcome, agriculturists have cut down their grounds under various products, leaving the land neglected. Consequently, the issue must be wrangled to see that 100-day work ensure under MGNREGA be limited entirely to months when there is no collecting or sowing action. MGNREGS has contributed considerably towards the financial strengthening of provincial ladies. With these benefits, the MGNREGS additionally has a few issues that need addressable. MGNREGS has a part in the climb of market wage of the workers. The wage rate settled by the MGNREGS goes about as a standard the lowest pay permitted by law beneath which the market compensation can't go in light of the fact that any such lessening would again prompt exchange of work from the agrarian part to the MGNREGS. Amid the overview it was additionally seen we likewise discovered brief span and transitory relocation among MGNREGA families.

\section{References:-}

1. Bhaduri A. (2005), "Development with Dignity. New Delhi: National Book Trust. 1-107 pp.

2. Department of Extension Education (2010), "A Study on the Performance of NREGS in Kerala, Gandhigram Rural Institute, Dindigul, Tamil Nadu. District Panchayat (2001) District Level Census Report 2001,

3. GoI (Government of India) (2008), "The National Rural Employment Guarantee Act 2005 (NREGA) Operational Guidelines, Ministry of Rural Development, New Delhi.

4. Gladson, D. (2008), "Plougher cut - Impact of NREGA. Tehelka Magazine, 5(37): 12-13.

5. GoK (Government of Karnataka) (2009) Chikmagalur District at a Glance, Bangalore.

6. Harish, B.G. (2010), "An Economic impact analysis of MGNREGA in Chikmagalur District of Karnataka.

7. Master's Thesis(Un-published). University of Agricultural Sciences, GKVK, Bangalore.

8. MGNREGS official website: http://nrega.nic.in Nair, K.N, Sreedharan, T.P. and Anoopkumar, M. (2009) A Study of National Rural Employment Guarantee Programme in Three Grama Panchayats of Kasargod.

9. NCEUS. (2006), "Social Security for Unorganized Workers. A Report. New Delhi: National Commission for Enterprises in the Unorganized Sector, Government of India.

10. Pillai et.al (2014), "socio-economic conditions of mgnrega programme workers in krishnarayrapuram taluk of karur district, ijmrr/ september 2014/ volume 4/issue 9/article no-10/932-939; issn: 2249-7196.

11. Rodgers G. (2009), "The Right to Work and the Reduction of Poverty: An Economists' View. New Delhi: Mimeo, IHD.

12. Ramesh, G. and Krishnakumar, T. (2009), "A study in Karimnagar district in Andhra Pradesh. Kurukshetra, 58 (2): 29-30.

13. Shankar, Raghuraman (2009), "NREGA is a promise half-kept. Times of India: 13 September. 